\title{
Refuge
}

Canada's Journal on Refugees

revue canadienne sur les réfugiés

\section{Crisis, What Crisis? Immigrants, Refugees, and Invisible Struggles}

\section{Anna Carastathis, Aila Spathopoulou et Myrto Tsilimpounidi}

Volume 34, numéro 1, 2018

Intersectional Feminist Interventions in the "Refugee Crisis"

URI : https://id.erudit.org/iderudit/1050852ar

DOI : https://doi.org/10.7202/1050852ar

Aller au sommaire du numéro

Éditeur(s)

Centre for Refugee Studies, York University

ISSN

0229-5113 (imprimé)

1920-7336 (numérique)

Découvrir la revue

Citer cet article

Carastathis, A., Spathopoulou, A. \& Tsilimpounidi, M. (2018). Crisis, What Crisis? Immigrants, Refugees, and Invisible Struggles. Refuge, 34(1).

https://doi.org/10.7202/1050852ar
Résumé de l'article

Différentes évocations liées au terme " crise » créent des catégories distinctes qui, à leur tour, sont évocatrices de réactions sociales particulières. Depuis 2008, la Grèce est devenue l'épicentre de la " crise financière "; depuis 2015, avec l'apparition de la " crise des réfugiés ", ce pays est aussi devenu le " hotspot de l'Europe ». Quels sont les différents vocabulaires de crise? Plus encore, comment ces deux représentations de crise ont-elles favorisé la perception des crises humanitaires en tant que phénomène de la gestion institutionnelle transnationale? Quels sont les sujets des différentes crises qui ont été construits de manière hégémo-nique? La réalité quotidienne en temps de crise au « hotspot de l'Europe » est invisible dans ces représentations. Ce sont précisément les réalités quotidiennes, intangibles, vécues et non dites des crises intersectionnelles que les discours hégémoniques des crises successives, des crises superposées ou des « crises emboîtées » rendent invisibles. En déplaçant le centre d'intérêt des catégories définies par l'état, et des personnes qu'elles regroupent, à une description plurivoque ouverte des oppressions capitalistes, nous avons pour objec-tif de questionner les efforts des états et les efforts suprana-tionaux pour répartir la " foule des migrants " en catégories juridiques distinctes de citoyens (émigrés), réfugiés, et immigrants illégaux, et déstabiliser ainsi les luttes de coalition entre les groupes précarisés.
Copyright (c) Refuge: Canada's Journal on Refugees, 2018

Creative Commons Attribution NonCommercial 4.0 International License
Ce document est protégé par la loi sur le droit d'auteur. L'utilisation des services d'Érudit (y compris la reproduction) est assujettie à sa politique d'utilisation que vous pouvez consulter en ligne.

https://apropos.erudit.org/fr/usagers/politique-dutilisation/ 


\title{
Crisis, What Crisis? Immigrants, Refugees, and Invisible Struggles
}

\author{
ANNA CARASTATHIS, AILA SPATHOPOULOU, AND MYRTO TSILIMPOUNIDI
}

\section{Abstract}

Different evocations of "crisis" create distinct categories that in turn evoke certain social reactions. After 2008 Greece became the epicentre of the "financial crisis"; since 2015 with the advent of the "refugee crisis," it became the "hotspot of Europe." What are the different vocabularies of crisis? Moreover, how have both representations of crisis facilitated humanitarian crises to become phenomena for European and transnational institutional management? What are the hegemonically constructed subjects of the different crises? The everyday reality in the crisis-ridden hotspot of Europe is invisible in these representations. It is precisely the daily, soft, lived, and unspoken realities of intersecting crises that hegemonic discourses of successive, overlapping, or "nesting crises" render invisible. By shifting the focus from who belongs to which state-devised category to an openended, polyvocal account of capitalist oppressions, we aim to question the state's and supranational efforts to divide the "migrant mob" into discrete juridical categories of citizens (emigrants), refugees, and illegal immigrants, thereby undermining coalitional struggles between precaritised groups.

\section{Résumé}

Différentes évocations liées au terme "crise» créent des catégories distinctes qui, à leur tour, sont évocatrices de réactions sociales particulières. Depuis 2008, la Grèce est devenue l'épicentre de la "crise financière»; depuis 2015, avec l'apparition de la "crise des réfugiés", ce pays est aussi devenu le "hotspot de l'Europe». Quels sont les différents vocabulaires de crise? Plus encore, comment ces deux représentations de crise ont-elles favorisé la perception des crises humanitaires en tant que phénomène de la gestion institutionnelle transnationale? Quels sont les sujets des différentes crises qui ont été construits de manière hégémonique? La réalité quotidienne en temps de crise au «hotspot de l'Europe" est invisible dans ces représentations. Ce sont précisément les réalités quotidiennes, intangibles, vécues et non dites des crises intersectionnelles que les discours hégémoniques des crises successives, des crises superposées ou des "crises emboîtées" rendent invisibles. En déplaçant le centre d'intérêt des catégories définies par létat, et des personnes qu'elles regroupent, à une description plurivoque ouverte des oppressions capitalistes, nous avons pour objectif de questionner les efforts des états et les efforts supranationaux pour répartir la "foule des migrants" en catégories juridiques distinctes de citoyens (émigrés), réfugiés, et immigrants illégaux, et déstabiliser ainsi les luttes de coalition entre les groupes précarisés.

\footnotetext{
The way we treated migrants and refugees won back our dignity; we showed that we too have dignity. I do not distinguish between refugees and migrants. The one is not innocent while the other is guilty. We must become familiar with the notion of the migrant, not
}

(ㄷ) Anna Carastathis, Aila Spathopoulou, and Myrto Tsilimounidi, 2018. This openaccess work is licensed under a Creative Commons Attribution-NonCommercial 4.o International Licence, which permits use, reproduction, and distribution in any medium for non-commercial purposes, provided the original authorship is credited and the original publication in Refuge: Canada's Journal on Refugees is cited.
Cette ouvre en libre accès fait l'objet d'une licence Creative Commons Attribution-NonCommercial 4.0 International License, laquelle autorise l'utilisation, la reproduction et la distribution de l'œuvre sur tout support à des fins non commerciales, pourvu que l'auteur ou les auteurs originaux soient mentionnés et que la publication originale dans Refuge: revue canadienne sur les réfugiés soit citée. 
only that of the refugee. We have refugees and migrants. We mustn't be afraid to use the term migrant, nor should we hide behind the notion of the refugee.

-Yiannis Mouzalas, former Greek minister of migration policy ${ }^{1}$

$\mathrm{A}$ $t$ the end of June 2017, Yiannis Mouzalas, the minister of migration policy of Greece, unveiled a public awareness campaign created by the International Organisation of Migration (IOM) in collaboration with the ministry: "Stop Mind Borders" targets stereotypes and prejudices against foreigners. ${ }^{2}$ Drawing on the experiences of racism faced by diasporic Greeks, the campaign asserts that the most important borders are those in our minds. The precise meaning of the minister's remarks in the context of the campaign is unclear. On the one hand, by evoking Greek migrants' experiences of racism in France, Germany, Australia, the United States, and Canada, he seems to call for the abolition of the internalized borders between "natives" and "foreigners" and to mobilize empathy and solidarity with targets of racism, by emphasizing the interchangeability of positions between "hosts" and "guests," "perpetrators" and "victims." On the other hand, he is justifying institutionalized divisions between "refugees" and "migrants" (and, implicitly, "citizens," whom the television spots address as their audience). He urges "us" not to "hide behind the figure of the refugee" in order to recognize that "we have refugees and migrants" in Greece. If, morally, he refuses to draw a distinction between them-"the one is not innocent while the other is guilty," he nevertheless reasserts the existence of the two discrete categories. Why is this division between migrants and refugees so important to underscore in the context of an anti-racist campaign? What is the relationship between these forms of attitudinal racism and the categories of migrant and refugee that the minister invokes?

This divisions between refugees, migrants, and citizens is at the heart of the hotspot logic, and the main thread running throughout this article is the way in which different evocations of crisis create distinct categories that in turn evoke certain social reactions. After 2008 Greece became the epicentre of the "financial crisis"; simultaneously, since 2015 with the advent of the "refugee crisis," it became the "hotspot of Europe." Arguably, to become the latter, it first had to become the former. It is not incidental that in 2015 Greece was threatened with removal from the Schengen zone if it did not comply with the deadline of February 15, 2016, to implement the hotspot mechanism. This paralleled simultaneous threats of Grexit from the European Monetary Union if the Greek Parliament did not ratify the third memorandum agreement with its institutional lenders. On the other hand, the Greek state in its public discourse linked the two crises, arguing that without the assistance of the European institutions it could not adequately deal with the emergency of nearly a million refugees arriving on its shores, because it was beleaguered by economic crisis. The hotspot became the means through which Greece was reinstituted as a sovereign state in dominant representations, while the unruly flows were used as a "bargaining chip" in its negotiations with the Troika (International Monetary Fund, European Central Bank, European Commission).

We want to unpack the ways in which the first crisis was not resolved but was transformed discursively and institutionally into the second crisis. What are, then, the different vocabularies of crisis? Moreover, how have both representations of crisis facilitated humanitarian crises to become phenomena for European and transnational institutional management? What are the hegemonically constructed subjects of the different crises? According to this hegemonic logic, the financial crisis produced (economic) emigrants-Greek citizens moving to Global North countries-while the refugee crisis (obviously) produces refugees. In the first instance, what is discursively marginalized is the inward and outward migration of non-Greeks, many of whom, already precarious, living through the crisis, lost their jobs and therefore their right to remain (or were undocumented to begin with). In the second instance, a hierarchy of suffering is constructed, whereby Europe is facing a severe refugee crisis, and the already financially imperilled nation-state that functions as its "gateway" is "burdened" by the task of separating legitimate refugees from illicit migrants and identifying "terrorists," who are hiding in the midst of "uncontrollable flows."

The politically urgent question to be asked is why the state would benefit from this separation between citizens, migrants, and refugees. We aim to explain that these realities are separate only in the technocratic Eu documents drafted behind closed doors in Brussels; also, these categories are invented by states in order to control movement. The everyday reality in the crisis-ridden hotspot of Europe is invisible in these representations. It is precisely the daily, soft, lived, and unspoken realities of intersecting crises that hegemonic discourses of successive, overlapping, or "nesting crises"3 render invisible. By "nesting crises" we are referring to the dominant state discourse of a crisis within a crisis giving temporal and spatial priority to the "sovereign debt crisis" while the refugee crisis is constructed as a sudden problem first emerging in the summer of 2015. This renders invisible its prehistory, namely the criminalized migration of people into the Greek territory and the relegation of long-standing migrant and refugee communities in Greece to the sociolegal margins of the society. By intersecting the discursive constructs of the financial crisis and the refugee crisis, what becomes visible is their constitution through mutual exclusion and prototypicality: the prototypical subject of 
the "financial crisis" is the Greek citizen, while that of the "refugee crisis" is the displaced Syrian family who deserve international protection. Here, we use the concept of intersectionality drawn from black feminist thought ${ }^{4}$ to show how dominant constructions of crisis create their normative victims, marginalizing experiences of social groups who are denied representational power. By shifting the focus from who belongs to which state-devised category to an openended, polyvocal account of capitalist oppressions, we aim to question the state's and supranational efforts to divide the "migrant mob"5 into discrete juridical categories of citizens (emigrants), refugees, and illegal immigrants, thereby undermining coalitional struggles between precaritised groups.

In this light, the article begins by unravelling the vocabularies of crisis in order to make visible the connections between financial precarity, ongoing marginalization of different strands of the population, and implementation of the logic of the hotspot. It then moves to an analysis of the trajectories that have led to the intervention and the financial "rescue" of the country by the Troika and then the sealing of its borders by Frontex (European Border Agency). Following this pathway, it becomes evident that the logic of the hotspots was introduced in the years before the "refugee crisis" was declared. Here we make a threefold distinction between the hotspot mechanism, the logic of the hotspot, and the representation of the hotspot. By hotspot mechanism we refer to the approach to migration management outlined in 2015 by the European Commission (described in detail in section two of this paper). This approach embodies a logic, which nevertheless precedes it, of a state of emergency that can be managed only through the institution of a state of exception. Hotspot logic refers to the arrogated right of the state to define and divide people into certain categories, such as the refugee, the grantee of subsidiary protection, the asylum seeker, the vulnerable refugee, the unaccompanied minor, the economic migrant, etc. Finally, we use the word hotspot to refer to a representation generated by the hotspot mechanism, which spatially exceeds the actual migration management infrastructure and ends up being ascribed to entire islands, cities, and countries. For example, this spatial slippage is naturalized by the media spectacle of the scene of arrival in Lesvos, and the whole island is referred to as the hotspot of Europe. Moreover, after the EU-Turkey deal of 2016, Greece as a country is characterized as the hotspot of Europe-like the hotspot infrastructure, first becoming a space of transit and then a space of detainment.

In the second section, we trace how the imposition of the hotspot regime has been legitimized by the discursive construct of the "refugee crisis." After shedding light on some of these concerns, the third part of the article is preoccupied with the ways the two crises create different categories of precarity, marginalization, and displacement. And, furthermore, how these categories then define who deserves "protection," asylum, and the potential for a future within the borders of the European Union. Worse still, these state definitions trickle down to shape our conceptions of solidarity-even if their contestation on the ground offers promising directions for reconceptualizing vocabularies of solidarity in times of intersecting crises.

\section{Vocabularies of Crisis}

Crisis is seen as a perpetual frame-breaking moment that, for people on the ground, dismantles the certainties and normative narratives of nation, sovereignty, social bonds, and belonging. The first superficial meaning of the word refers to a sudden change, a temporal interruption of a condition of normality. As such, the first etymological unpacking of the term crisis presupposes a former state of normality interrupted by a temporal rupture, after which we imagine that ultimately normality and normativity will return. ${ }^{6}$ Following this logic, crisis is nothing more than a temporary, unstable period that will inevitably lead back to normativity. To quell suspicions that we are stuck waiting for nothing to happen, we are told by the UNHCR that refugees are resettled within fifteen years and by the Troika that debt payments will be completed in 2057, implying a resolution of "crisis." In this light, narratives of crisis are animated by spectres of a preexisting state of normative trajectories (a non-indebted welfare state or a peaceful existence free of violence) that perpetuate the notion that crisis is a schism in normality that will eventually be mended. In other words, crisis refers to a moment of exception, but a curable one (if one swallows the prescribed "bitter pill"). Instead, the economic crisis and its ramifications become a (seemingly) permanent state of being. The result is a deep political and social sense of uncertainty, precarity, and dispossession. Taking into consideration the geopolitical shifts in the Mediterranean and Central Asia in the last decades (Arab Spring, wars in Afghanistan, Iraq, and Syria), it seems empirically impossible to foresee a return to normality, not least of all since it never existed.

What needs further unpacking, then, is the interdependency between the dominant understanding of crisis and the implied return to normativity. In most debates about the current crisis, questions about the future are limited to asking when things will return to "normal." In other words, the massive social and political shock of the crisis and the destruction of the material conditions it imposes create nostalgia for what existed "before," an uncritical acceptance of the conditions before the crisis. Moreover, a nostalgic society caught in the etymological trap of the temporal character of the crisis is a society held in suspension, spatially and temporally captive. Thus crisis evokes a certain embodiment of 
time, since the past presents a haunting nostalgia, the present is in crisis, and the future becomes increasingly impossible to imagine or picture. The only meaningful future is constructed through a romanticized and nostalgic remembrance of the past. In short, crisis breaks the linear contract of time: looking back seems like the only way forward. ${ }^{7}$

What then is important to this discussion of the vocabularies of crisis is the notion that the future is now entirely uncertain or not a future at all, since it is the reproduction of a past that never was. On all sides, the sense of self, security, and capacity to resolve the crisis is being questioned. One of the most vividly invoked threats to the national self relies on medical metaphors, one of the favourite rhetorical schemas in the construction of crisis narratives. Crisis is a disease that needs to be quarantined and contained, whether the risk is "contagion" to the Eurozone, or "hygienic" threats to the populace. ${ }^{8}$ Crisis suggests not only the necessary climax of a natural process, but also proposes the "cure": for example, the sweeps and arrests of HIV-positive users of intravenous drugs who are constructed as threats to "Greek family men" and are charged with intention to cause grievous bodily harm for selling sex (though none are actually found to have been). ${ }^{9}$ It is not incidental that Health Minister Andreas Loverdos characterized the arrested women as a foreigners constituting a hygienic bomb and a threat to the health of the Greek family (despite that fact that all the arrested women except one were Greek nationals). To take another example, structural adjustments prescribed by IMF Director Dominique Strauss-Kahn were characterized as unpleasant medicine you for your own good, ${ }^{10}$ and in the first memorandum, as the "bitter pill" needed to prevent the disease from spreading. ${ }^{11}$ This kind of medical metaphor treats crisis as process, something inevitable that was meant to happen.

The process of naturalizing the financial crisis leaves no room for questioning the structures, decisions, and value systems that brought us to this state of greed, consumption, and corruption. Accordingly, the naturalization of the refugee crisis locates the problem in the arrival of refugees on Greek shores and leaves unquestioned the imperialist war, dictatorship, and displacement that are its root causes. To put it differently, the crisis is constructed as the effect rather than the cause. Moreover, nation-states and continents are figured as though suffering the crisis rather than people facing poverty, displacement, and violence. Thus, this discussion is focused on finding the right cure, and the ones who are attributed with the knowledge to do so are financial experts, political elites, and humanitarian experts. The curewhether it is the imposition of structural adjustments or the "triggering" of the hotspot mechanism-is delivered in highly technocratic language that leaves no room for any other kind of negotiation; at the same time, non-experts (almost every strand of the population) are put in the position of the mere observer. In the narrative of medical metaphors, nations are sick, not their banks or financial sectors; whole countries or their nationals need to be quarantined and contained rather than the global investments of bonds and capital. It is standard practice for agents of Frontex, coastguards, and military police to be issued gloves and masks for use when arresting refugees. Not only is crisis being naturalized, but also the reasons for its appearance are to be sought in the social body, and this further opens the space for characterizations of whole populations, such as the lazy and tax-evading Greeks are responsible for the financial collapse of "their" economy; the cowardly and opportunistic Syrians are seeking asylum in Europe rather than staying behind to defend "their" country.

This is a religious discourse according to which crisis has fallen upon us like a natural disaster, as punishment for our sins: corruption, profligacy, tax evasion. ${ }^{12}$ And it is precisely this guilt that minimizes the potential for resistance against crisis and austerity, because crisis is the unavoidable (and even desirable) punishment for our sins, a situation that we must passively endure if we want to reach a moment of purification. In a sense, the "refugee crisis" has provided this possibility of redemption, and a renewed sense of dignity for "Greeks," as indicated in Mouzalas's remarks in the epigraph. The civil society mobilization in response to the "refugee crisis" was invoked in state discourses as currency in a moral economy that sought to transform the prevalent perception of Greeks in the EU and beyond-from corrupt and tax-evading freeloaders to paradigms of hospitality and exemplars of "European" values of solidarity. A social body trapped in the spiral of sin and redemption appears to be waiting for its ultimate saviour: the prime minister who will stand up to the country's lenders, setting course for the promised land of financial security; or Germany-the destination imagined by many refugees arriving in Greece whose only demand is represented as to be allowed to "go on to Europe." The sinner and the saviour then become established categories with their own racial, cultural, religious, and aesthetic characteristics. The most obvious example on a pan-European level is the migrant sinners who are "taking our jobs" and "take advantage of the welfare system." In the transient state of crisis, the social body busies itself identifying new sinners and experiencing collective guilt, or collective exaltation, which prevent it from organizing an effective resistance. Thus crisis functions as an opportune moment for the implementation of policies that would otherwise be controversial, since these reforms address not only political or economic exigencies, but seem to satisfy deep "spiritual" needs forged through religious discourses.

If we are to move away from mainstream, populist vocabularies of "crisis" that are hegemonic, can we arrive at a more 
dynamic, open-ended understanding of the phenomena they occlude, in addition to those they name. Indeed, the

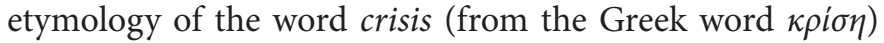
suggests that in addition to the first sense of temporal interruption of a condition of normality, "crisis" also refers to the critical act of judgment and thinking, which indicates a space of meaningful self-reflection. Following this logic, crisis can be seen as an opportunity ${ }^{13}$ to redefine what had seemed unquestionable and fixed in years narrated as ones of development and prosperity. When the future is uncertain and suspended, the expected personal and social pathways seem more distant. Yet after the mourning of the loss of the grand narratives, a space opens up. It is in this space that the future awaits, together with the possibilities of different forms of organization and social action. As Craig Calhoun says, "Using the word crisis is commonly a way to try to get people to take action, to indicate that we have no choice but to do something. It is performative, not merely descriptive. It is a call to action."14 The direction of these actions is not certain; there is no such thing as an emancipatory promised space per se, but the shifting societies and politics offer valuable and challenging terrains for contestation. The question becomes how we can move from the state of emergency (crisis, precarity, displacement) to a state of transition (critique, resistance, occupation), and then to one of emergence (solidarity networks, different social formations, alternative economies). In the ten years of crisis, the perpetual state of emergency-aspects of which are named and others elided through the concept of "crisis" - has been transforming/ transitioning into a state of emergence, precisely by people struggling to survive wars and "wars by other means." Yet there is a border that runs through "crisis"; its concomitant discourses spatially and temporally create hierarchies of suffering, of human lives and deaths, in which those of the "European population" (however that is defined) is deemed of the highest order of importance. In the following section, we discuss how this border between crises is manifested through the hotspot logic.

\section{Vocabularies of Hotspots}

Welcome to Greece, a country on the European periphery after a decade of crisis. During the last ten years, the collapsing health-care system led to a public health crisis; ${ }^{15}$ youth unemployment increased to 65 per cent, which caused a serious "brain drain;"16 pensions and salaries were cut, leaving one-third of the population living below the poverty threshold. ${ }^{17}$ The country was variously named the "guinea pig" of Europe on which structural adjustments were tested, or the "pariah" of Europe responsible for the European crisis. ${ }^{18}$ In a way, one could claim that Greece-threatened with expulsion from the monetary union or the Schengen area-is the immigrant of Europe. In the same way that the immigrants are usually scapegoated as the reason for disorder within the limits of the nation state, Greece is scapegoated on a European level and accused of the destruction of Europe. ${ }^{19}$ Greece is not only held responsible for the financial collapse of the European Monetary Union but also for its inability to control and seal its borders, creating the worst refugee crisis in recent European history. Welcome to Greece, the "entrance gate" to Europe for most refugees and undocumented migrants. Welcome to Greece, where your presence as an immigrant and/or refugee is going to be used as the ultimate financial solution to the economic crisis. As the Greek state (and certain commentators) ${ }^{20}$ announced, this is a wonderful opportunity for Greece to navigate its way out of crisis-from "Grexit" to "Grecovery." ${ }^{21}$ And indeed the detention infrastructure grew widely after 2015, becoming one of the only sectors of the economy that was functioning. By "detention infrastructure" we are referring not only to prison-style detention centres in which undocumented people are incarcerated prior to deportation, but also to the hotspot mechanism through which people are confined to the islands. We also consider the camp a form of detention, since people are forced to live there after their receipt of international protection, instead of being integrated into the social fabric.

Since the summer of 2015, following the threat of a "Grexit" (a Greek exit from the European monetary union as a result of the "debt crisis" and the prospect of Greece defaulting on its loans), a new threat has been imposed on Greece: its possible expulsion from the Schengen zone, precisely because Greece has been increasingly deemed incapable of fulfilling its role as a premier watchdog at the Eu's border with Turkey. Five "registration and identification centres" started operating in Greece, on the islands of Lesvos, Chios, Samos, Leros, and Kos. The hotspot approach was presented by the European Commission in May 2015 as part of a larger policy push termed the "European Agenda on Migration."22 The agenda mandates the European Asylum Support Office, Frontex, and Europol to collaborate "with frontline Member States to swiftly identify, register and fingerprint incoming migrants," ${ }^{23}$ dividing those eligible to apply for asylum from those ineligible, who are slated for deportation. Further, Europol and Eurojust are to assist the "host" member state in the dismantling of "smuggling and trafficking networks." 24

"Crisis," understood through medical metaphors, discursively justified the implementation of a system of "quarantine," whereby the EU implemented the island detention model, known as the "Pacific Solution," imported from Australia. The land border with Turkey had already been sealed in 2012 with a $10.5 \mathrm{~km}$ fence, pushing refugees to make the more dangerous sea crossing and effectively ensuring their arrival on 
the Aegean islands that would come to be defined juridically as "hotspots." In the first year since the fence went up, the death toll of the sea crossing increased markedly. ${ }^{25}$ This leads to our question, what came first? The crisis or the hotspot?

According to the European Commission's "Explanatory Note on the 'Hotspot' Approach," what triggers the hotspot is a state's own request for assistance to deal with "unmanageable" "mixed flows": that is, people who will be categorized as asylum claimants, and those who will be denied the right to claim asylum and be deported directly from the hotspots. Rather than assume the self-evidence of these categories, it is important to note that this categorization is based mainly on nationality, but also on the date of arrival (prior to or after the EU-Turkey deal). Indeed, the hotspot system on the islands produces legal categories based on nationality; thus, the hotspot leads to an accelerated illegalization of most people who are channelled through its mechanism. ${ }^{26}$ Ironically, then, while the hotspot approach and the EU-Turkey deal claims to combat the "smuggling of migrants," it arguably proliferates clandestine routes, displacing them from the exterior to the interior of the national border-or, rather, displacing or multiplying the border itself.

The hotspots, as they are described by the Eu Commission, constitute an EU approach to "managing" what the Eu calls the "refugee/migration crisis": that is, the "mixed migratory flows" placing "disproportionate migratory pressure at [the] external borders" of "frontline Member states." 27 At the same time, we argue that the implementation of the hotspot approach cannot be analyzed separately from the "Greek crisis." The hotspots constitute an approach to managing migrants' "unruly" mobility and to managing what the EU constructs as a "rebellious" Greece, after ten consecutive years of economic "crisis," teetering on the verge of being declared a "failed state." Already relegated to an economic and symbolic periphery to legitimize the imposition of austerity measures by the Troika, the Greek state was threatened with removal from the Schengen zone if it did not complete construction of the five hotspots prior to the deadline of February 15, 2016, paralleling threats of "Grexit" from the European Monetary Union if it refused to implement mandated structural adjustments. Arguably, then, the hotspots on the Greek border islands have a double function: first, to identify, classify, and segregate people arriving on the islands, channelling and regulating their mobility thereafter; and second, to secure Greece's faltering "Europeanness." In other words, as ordering mechanisms, they "border" both the migrants and the islands: hotspots produce or enforce a border, classifying people into legitimate refugees and illegal economic migrants; and hotspots produce Greece as a border of Europe, or, indeed, as the "hotspot of Europe." 28 We refer to this as the double function of the hotspot, the "border within a border" erected to manage what has been termed in state discourses "a crisis within the crisis." 29

The question, therefore, is the extent to which notions of "Europeanness" become a tactically malleable and highly relative exchange value in relation to the convulsions of the expansive Eu border enforcement regime. From the standpoint of some of Europe's beleaguered borderlands, therefore, the deepening integration of military tactics and humanitarian techniques reappears not as a "solution" to the "crisis" of the border but rather as one more series of measures that will further escalate the (double) "crisis." When referring to the "refugee crisis," the Greek government emphasizes how Greece has shown a "human face" to the refugees arriving by boat on the Greek islands and has thereby purportedly exhibited its "European values." Emphatically contrasting this hospitality on the Greek islands with the implied or explicit allegation of "inhumanity" of the Turkish state, Greece effectively re-inscribes itself within "Europe" by depicting Turkey as the site, just beyond the borders of "Europe," where "the problem" of a "migration" or "refugee crisis" begins. As more and more Eu member states were sealing their borders, effectively closing the Balkan route, which refugees had been using in their attempt to move deeper into "Europe" since the summer of 2015, the media began constructing Greece as a "hotspot" within Europe-or rather at the edge of Europe. Greece was reconceived as a transit space, but one in which thousands of migrants were now stuck or stranded.

Still, hotspots have other functions beyond detention, such as the redistribution of those classified as asylum claimants or refugees on the Greek territory-and beyond; the "relocation" of those granted refugee status to "Europe"; as well as the criminalization and deportation of "economic migrants" (or of refugees back to the "safe third country" of Turkey). These functions beyond detention are experienced unevenly by people pushed into these categories, given the construction and management of "mixed flows": that is, the juridical entitlement of the EU to criminalize migration by denying international protection to those who cannot prove their persecution is "political." Using the naturalizing logics of time and space, the state attempts to divide the "migrant mob" 30 into discrete, self-evident nationalities and to divide refugees and migrants from each other, but also from the local society, including established migrant communities. The cynical use of the islands' topography to divide the social body is a transnational, trans-historical technology of fascism: "unruly" political exiles were sent to remote islands during the junta in Greece, while the Australian offshore prisons of Nauru, Manus, and Christmas Island were exported as the "Pacific Solution" to stemming "unmanageable flows."

If seeking asylum has become synonymous in many jurisdictions with immediate (and sometimes indefinite) 
detention, the hotspot model is about pushing the border to the mainland, refusing passage to the city, and facilitating the eu's segregation and deportation projects. Resistance in and to this bordered reality means denaturalizing the logics through which land, sea, and sky become prisons. How we want to live, that we want to live, where we want to live, with whom, and for what-these are the simple decisions people negotiate through our struggles to a transnational regime that tries to run a border through our very existence.

\section{Intersecting Crises beyond State Categories}

Intersecting the vocabulary of "financial" crisis with the vocabulary of "refugee crisis" reveals the indebtedness and contingency of both discursive constructs to the nation-state and the foundational categories that it invents to manage human mobility through time and space. In the previous sections, we contrasted the currency and mobility of these vocabularies of crisis to their immobilizing effects on human lives. Elsewhere we introduced the concept of the "mobile hotspot" to examine how the hotspot, as a condensation of the border, follows people who have passed through it into the interior of the national state and beyond. ${ }^{31}$ Intensifying the border, we argue, the hotspot is not just a spatial entity on the islands where people are made to register, are sorted out, fingerprinted, and classified as deserving or undeserving of international protection; it is a space of administrative violence that, in an accelerated manner, inscribes the ideological-juridical distinction between legitimate supplicants and undeserving "economic migrants" in detainable, deportable, and disposable human bodies. Keeping people in a state of perpetual immobility at and within the territorial border of the nation-state, Greece as the hotspot of Europe seeks to redeem itself in the geopolitical project of Continental integration.

The question "What crisis?" urges a destabilization of the border that runs through crisis. With the declaration of the "refugee crisis," the state sought to re-establish its faltering sovereignty by reasserting its borders. Locating the state itself as the victim of "unmanageable flows," the implementation of the hotspot system on the Greek border islands helped transform EU migration policy, but also to defuse anxieties about Greece's diminished national sovereignty. After all, borders are the naturalized limits of the sovereign nation-state. Yet efficiency and rationality have replaced the institutionalized "Greek" racism exemplified in the era of "Xenios Zeus" ("hospitable Zeus"), where the Greek state conducted police sweeps of the city-centre of Athens to identify undocumented persons by racial profiling. ${ }^{32}$ Such "primitive" methods are now replaced with a bureaucratic infrastructure that "sorts" people at all stages of their journey and tracks them in perpetuity. Thus our everydayness in the hotspot of Europe is being spatially and temporally fragmented through a proliferation of crisis logics. In other words, living in a hotspot refers to the spatialities and temporalities generated by the ways in which our very existence-in a bordered reality-has come to be constructed and perceived through the vocabulary of "crisis." Yet the same violence as "before the crisis" is still taking place now, but now it is rationalized by the vocabularies of neoliberal crisis management.

Crisis-in its soft, lived, invisible dimensions-constitutes the daily violence of the operation of oppressive systems. Capitalism loves a crisis, the nation-state needs harsher borders, and our inability to view crisis outside or beyond the categories invented by state projects means that the hierarchies of suffering that useful crises (as opposed to accidental or unforeseeable ones) produce go uncontested. Why are "refugees welcome" while immigrants remain "illegal"? Why did a housing occupation movement emerge (and gain international visibility) only with the arrival of refugees, while a massive increase in homelessness within a year of the imposition of austerity measures barely registered as a political (and not merely a "social") problem? Why is the Greek state collaborating with the IOM to combat racist prejudices now, when institutionalized racism has targeted immigrants for decades? And why are the experiences of emigrants (Greek nationals) constructed as morally or affectively legible in these campaigns?

Taking an intersectional approach to crisis discourses can reveal who is pushed to the margins through their mutual exclusion. Constructing the "financial crisis" as a "Greek problem" renders invisible the struggles of people residing and working in the Greek territory (often for decades, sometimes having been born here) who are denied citizenship or even permanent status and are perceived as increasingly unwelcome "guests" under conditions of austerity. Relegated permanently to the socio-legal position of outsiders, even fascist attacks on non-nationals are justified by the hostile climate of austerity, while their experiences of unemployment, loss of legal status, homelessness, and return migration do not figure as effects of the "sovereign debt crisis." 33 On the other hand, constructing the "refugee crisis" as a sudden event with a determinate historical beginning-like a natural disaster-enables the histories and trajectories of forced migration over the past three decades to be forgotten, and the precarity to which "illegal immigrants" (as they were castigated in dominant discourses) were subjected in Greece. It is worth recalling that prior to the institution of the hotspot mechanism, asylum applications in Greece were approved at a rate of less than 1 per cent; a mere year after the declaration of the "refugee crisis," and six months after the implementation of the EU-Turkey deal, approval rates have descended to nearly the same level (1.23 per cent between July 21, 2016, and 
March 31, 2017). ${ }^{34}$ Moreover, intersecting the "financial crisis" with the "refugee crisis" means rejecting the false division between the economic and the political, between class and citizenship, between elective and forced migration. These (and other undeclared crises) are intersecting crises in the sense that they converge in people's lives (e.g., those migrating to escape endemic poverty due to structural adjustment policies, or debt colonialism).

Returning to Mouzalas's words with which we began, citizens are those who are empowered to understand that "the one [refugee] is not innocent, while the other [immigrant] is guilty." Mouzalas's explicit aim is to refute racial animus; but the implicit meaning of what he is saying becomes clear if we examine the infrastructure behind the anti-racist campaign. The former produces racial categories, while the latter denounces their use by citizens. Citizens should not be suspicious of foreign others in an age of migration management, which enables the state to ensure their safety by dividing the "dangerous" from the "deserving" who make it across the border. In this sense, while reaffirming that migrants are always already guilty-criminalized by definition-Mouzalas implies the refugee is not (always) innocent, or cannot be assumed to be. It is not incidental that, in order to be relocated, refugees have to undergo a "security" interview, where they are asked their opinion about such matters as the terrorist attacks in France or Germany. The administrative mechanism probes their guilt, in order to determine who are properly "innocent" and politically innocuous, and who pose a threat.

Those who have lived in Greece with precarious, undecided, or temporary status for decades are irrelevant in the sense that the "refugee crisis" has completely marginalized them: their asylum claims or stay applications have been on hold for years, constantly being postponed, while (at least some) people who arrived months ago have already been relocated. Somehow the arrival of the former in Greece never constituted a "crisis" for anyone but themselves. Moreover, they are now being invited to staff the hotspot infrastructure, the NGO infrastructure, and even the military, to enable the state to exploit their linguistic and cultural "capital." For many people who have been on the edge of the margin precisely as a result of their migration status, finding work in the "emerging economy" 35 of migration management comes as a relief after having suffered (possibly more than) ten years of unemployment, of inaccessible education, of loved ones departing, of being unable to visit loved ones-of waiting, for nothing to happen.

But now something is happening that at first seemed to change everything. A demoralized, demobilized people were awakened to solidarity (or so the representation goes) with people arriving who had suffered worse than they or had just suffered things they themselves had once suffered. Grandmothers who were internally displaced during the German occupation were welcoming "refugees" into their homes in middle-of-nowhere villages. ${ }^{36}$ Even nationalists and philhellenes were lobbying to have the country nominated for a Nobel Peace Prize.37 As Mouzalas says, "We won back our dignity." But it is only in representations that "we" ever lost it.

\section{In Lieu of Conclusion}

\section{Research Extract: The Mother of All Crises ${ }^{38}$}

To live in an era of crisis means to cultivate the ability to cope with sudden, unpredictable changes. Yet in order to be successful in these navigations you have to establish a stable point of reference, a checkpoint that would always be there. From that static point you can measure the effects of sudden shifts on your own personal, professional, and affective landscape.

Since crisis is endemic to capitalism and to the smooth functioning of our economic systems, if you position yourself against the procedures of capitalist accumulation by dispossession you reach a point from where resistance towards this process is directed against state institutions that reproduce hierarchies, stereotypes, and power relations. So instead of blaming the migrants, the pariahs, and in general the people who cannot fit the cognitive, aesthetic, and dominant territories, you start to question the processes that dictate who belongs where.

All these make sense on a spectacular level, but spectacle is, after all, the monopoly of the state. Like the mother of all bombs-the bomb that makes the least noise but has the biggest geographical spread and creates the highest death toll-the mother of all crises is silent, invisible, and mundane. It doesn't make it to the headlines, but it affects the ways we live, survive, and imagine. It violently escapes our categorizations and, like a heroine in an ancient theatre, wears many masks. It is present when we say goodbye to friends who emigrate for a "better future," when our parents do not have access to health care, or when we feel guilty for entering our house in a city where so many people sleep rough.

Checkpoint, reference point, safe ground. What are the mind borders we inhabit while we are surviving crises?

\section{Notes}

1 Michail Aggelos Konstantopoulos, "Refugees and Migrants Confront Our 'Mind Borders," Efsyn, 2 July 2017, 69 (our translation from the Greek, emphasis added).

2 Greek Annex of the International Organisation for Migration, "Stop Mind Borders" (2017), https://youtu.be/POHhkZFAH9M; https://youtu.be/D8O24DoGdwg; https:// youtu.be/BjM-uo3 $\mathrm{A}_{7} \mathrm{Y}_{4}$. 
3 Anna Carastathis, "Nesting Crises," Women's Studies International Forum (2017), https://doi.org/10.1016/j. wsif.2017.11.007.

4 Kimberlé Williams Crenshaw, "Demarginalizing the Intersection of Race and Sex: A Black Feminist Critique of Antidiscrimination Doctrine, Feminist Theory and Antiracist Politics," University of Chicago Legal Forum 140 (1989): 139-67.

5 Martina Tazzioli, "The Government of Migrant Mobs: Temporary Divisible Multiplicities in Border Zones," European Journal of Social Theory (2016), http://dx.doi.org/10.11 $77 \% 2 \mathrm{~F} 1368431016658894$.

6 Myrto Tsilimpounidi, Sociology of Crisis: Visualising Urban Austerity (London: Routledge, 2017).

7 Tsilimpounidi, Sociology of Crisis, 80.

8 Miguel-Anxo Murado, "Spain's Economic 'Apocalypse' Defies Europe's Web of blame," Guardian, June 5, 2012, http://www.theguardian.com/commentisfree/2012/ jun/05/spain-eurozone-blame-crisis; Pew Research Centre on Global Attitudes and Trends, "The New Sick Man of Europe: The European Union" (2013), http://www .pewglobal.org/2013/05/13/the-new-sick-man-of-europethe-european-union/; Remy Davison, "Greece Can't Be Quarantined, so Europe Will Keep on Giving It Medicine," Conversation, July 19, 2011, http://theconversation.com/ greece-cant-be-quarantined-so-europe-will-keep-on-givingit-medicine-2377.

9 Zoe Mavroudi, Ruins: Chronicle of an HIV Witch-Hunt (2013): film, 54 minutes (in Greek with English subtitles).

10 Strauss-Kahn quoted in Prime Minister's Press Office, "Meeting with Dominique Strauss-Kahn, Statements," 2010, accessed August 1, 2017, http://www .primeminister.gov.gr/english/2010/12/o7/meeting-withdominiquestrauss-kahnstatements/.

11 European Commission. The Economic Adjustment Programme for Greece (Brussels: European Union, 2010), http://ec.europa.eu/economy_finance/publications/ occasional_paper/2010/pdf/ocp61_en.pdf.

12 Slavoj Žižek, "The Urgent Necessity of a Syriza Victory in Greece," In These Times (2015), http://inthesetimes.com/ article/17561; Costas Douzinas, Philosophy and Resistance in the Crisis: Greece and the Future of the Eurozone (Cambridge: Polity, 2013).

13 This is not the same as the opportunistic logic of the financial experts and investors who see crisis as an opportunity to foresee and discover the next crash so they can increase their profits.

14 Craig Calhoun, "From the Current Crisis to Possible Futures," in Business as Usual: The Roots of the Global Financial Meltdown, ed. Craig Calhoun and Georgi M. Derluguian, 9-42 (New York: New York University Press, 2011).

15 Alexander Kentikelenis, Marina Karanikolos, Aaron Reeves, Martin McKee, and David Stuckler, "Greece's Health Crisis: From Austerity to Denialism," Lancet 383, no. 9918 (2014): $748-53$.
16 Costas Lapavitsas, Crisis in the Eurozone (London: Verso, 2012).

17 Ian Traynor, "Crisis over in the Eurozone? Not in the Real World," Guardian, October 9, 2013, http://www .theguardian.com/business/2013/oct/og/crisis-overeurozone-not-real-world.

18 Costas Douzinas, Philosophy and Resistance in the Crisis: Greece and the Future of the Eurozone (Cambridge: Polity, 2013); Jon Henley, "Meeting the eu's Lost Generation," Guardian, June 6, 2013, http://www.theguardian.com/world/ blog/2013/jun/o6/meeting-eu-lost-generation-jon-henley.

19 Costas Douzinas, Syriza in Power: Reflections of an Accidental Politician (London: Wiley, 2017).

20 See, for instance, Gideon Rachman, "Greek Debt Is the Key to the Refugee Crisis," Financial Times, January 25, 2016, https:// www.ft.com/content/afefff32-c347-11e5-808f-8231cd71622e.

21 Prime Minister's Press Office, "Speech of the Prime Minister and President of New Democracy Mr Antonis Samaras at the 9th Regular National Congress of the Party," 2013, accessed August 1, 2017, http://www.primeminister.gov .gr/2013/o6/28/12258 [in Greek].

22 European Commission, "Explanatory Note on the 'Hotspot' Approach," Statewatch (2015), http://www.statewatch.org/ news/2015/jul/eu-com-hotsposts.pdf.

23 European Commission, "Explanatory Note."

24 European Commission, "Explanatory Note."

25 Amnesty International, The Human Cost of Fortress Europe: Human Rights Violations against Migrants and Refugees at Europe's Borders (London: Amnesty International, 2014), 11.

26 Martina Tazzioli, "Identify, Label, and Divide: The Accelerated Temporality of Control and Temporal Borders in the Hotspots," Society \& Space (2016): http://societyandspace .org/2016/11/22/identify-label-and-divide-the-temporalityof-control-and-temporal-borders-in-the-hotspots/.

27 European Commission, "Explanatory Note," 2.

28 Heath Cabot, "Crisis, Hot Spots, and Paper Pushers: A Reflection on Asylum in Greece," Cultural Anthropology (2016): https://culanth.org/fieldsights/898-crisis-hot-spotsand-paper-pushers-a-reflection-on-asylum-in-greece; Evthymios Papataxiarchis, "Being 'There': At the Front Line of the 'European Refugee Crisis'-Part One." Anthropology Today 32, no. 2 (2016): 5-9, http://dx.doi.org/10.1111/14678322.12237.

29 Prime Minister of Greece, "Declarations of the Prime Minister Alexis Tsipras after the Conclusion of the Governmental Summit for the Management of Issues Related to Refugee Flows," Office of the Prime Minister, 2015, accessed August 1, 2017. http://www.primeminister.gov.gr/2015/o8/o7/13931; Christodoupoulou quoted in Phoebe Greenwood, Noah Payne-Frank, and Apostolis Fotiadis, "The Greek Island Sinking under Europe's Refugee Crisis," Guardian, August 18, 2015, http://www.theguardian.com/world/video/2015/ aug/18/greek-island-leros-europe-migrant-crisis-video.

30 Tazzioli, "Government of Migrant Mobs." 
31 Aila Spathopoulou, "The Ferry as a Mobile Hotspot: Migrants at the Uneasy Borderlands of Greece," Society \& Space (2016): http://societyandspace.org/2016/12/15/ the-ferry-as-a-mobile-hotspot-migrants-at-the-uneasyborderlands-of-greece/.

32 Human Rights Watch, Unwelcome Guests: Greek Police Abuses of Migrants in Athens (New York: Human Rights Watch, 2013).

33 Anna Carastathis, "The Politics of Austerity and the Affective Economy of Hostility: Racialized Gendered Violence and Crises of Belonging in Greece," Feminist Review 109 (2015): 73-95.

34 Deport Racism Movement, "Just over 1\% of Refugees Who Applied for Asylum Received International Protection," January 19, 2018, https://www.kar.org.gr/2018/o1/19/molis-to-1ton-prosfygon-pou-etithikan-asylo-elavan-diethniprostasia/.

35 Depression Era Collective, "The Tourists: A Campaign" (2017), http://depressionera.gr/tourists.
36 UNHCR, "Greece: The Refugees' Grandmother in Idomeni,” (2016) Video, 3:06 minutes, https://youtu.be/ Hb_Hdjy4CVw.

37 See the petition, "Nobel Peace Prize for Greek Islanders," Avaaz, https://secure.avaaz.org/campaign/en/nobel_prize_ greek_islanders_21/?pv $=81 \& \mathrm{rc}=\mathrm{fb}$.

38 Mytro Tsilimpounidi, field notes, July 7, 2017.

Anna Carastathis is an independent researcher. The author may be contacted at acarastathis@gmail.com.

Myrto Tsilimpounidi is Marie Curie Fellow at the Institute of Sociology, Slovak Academy of Sciences. The author may be contacted atmyrtotsil@gmail.com.

Aila Spathopoulou is a PhD candidate at Kings College University, London. The author may be contacted at islaspathopoulou@yahoo.com. 